\title{
Transfer of photosynthetic products in gelatinous colonies of Phaeocystis pouchetii (Haptophyceae) and its effect on the measurement of excretion rate*
}

\author{
M. J. W. Veldhuis ${ }^{1,2}$ \& W. Admiraal ${ }^{1,2}$ \\ ${ }^{1}$ Department of Marine Biology, University of Groningen, P.O. Box 14, 9750 AA Haren (Gn), The Netherlands \\ ${ }^{2}$ Netherlands Institute of Sea Research, P.O. Box 59, 1790 AB Den Burg (Texel), The Netherlands
}

\begin{abstract}
Colonies of the alga Phaeocystis pouchetii (average colony diameter ca $4 \mathrm{~mm}$ ) were subjected to light/dark periods in culture, and production and consumption of macromolecules of the colony matrix were measured. In the light, up to ca $32 \%$ of the total photosynthetic carbon fixation, consisting mostly of large-molecular-weight products ( $M W>$ 1800), were accumulated in the colonial matrix. In the dark, these macromolecular compounds disappeared, whereas monomeric and oligomeric compounds were found, suggesting reassimilation of colonial substances by $P$. pouchetii cells. Stepwise filtration allowed separate analysis of cells, colonial matrix and surrounding medium. The latter 2 compartments differed widely in size spectra of organic compounds (as determined by gel-permeation) and in fluctuations over a light/dark cycle, suggesting that the very high rates of carbon excretion during $P$. pouchetii blooms in previous reports should be reconsidered.
\end{abstract}

Introduction. Occurrence of algal mucilage is a wide-spread phenomenon not only found in association with macro-algae (Boney 1981); also phytoplankton blooms composed of certain diatom species (Boalch \& Harbor 1977, Round 1984) and the haptophycean alga Phaeocystis pouchetii (Bougard 1979) produce massive amounts of mucilage in the sea. The function of the gelatinous material may be very diverse. A mucilage envelope of the algal cells affects buoyancy (Walsby \& Reynolds 1980), whereas organization of cells in a colony also affects sinking rate (Smayda 1970). Organization of small algal cells into large colonies protects them in several circumstances against grazing by zooplankton (Joiris et al 1982, Pentecost

\footnotetext{
- This investigation was supported by the Foundation for Fundamental Biological Research (BION), which is subsidized by the Netherlands Organization for the Advancement of Pure Research (ZWO). Publication No. 101 of the project Ecological Research of the North Sea (EON)
}

1983, Reynolds \& Rodgers 1983). A slime cover over the algae may also prevent settlement of bacteria (Kugrens \& West 1973)

Production of mucilage in phytoplankton may also function as a metabolic overflow: Myklestad \& Haug (1972), and Haug \& Myklestad (1976) demonstrated that intracellular as well as extracellular carbohydrates accumulated in nutrient-limited cultures of diatoms. Guillard \& Hellebust (1971) and Lancelot (1984) demonstrated that Phaeocystis pouchetii excreted up to ca $60 \%$ of its fixed carbon, when growing at low concentrations of nutrients. In experiments with natural $P$. pouchetii populations Lancelot \& Mathot (1985) found polymeric substances to be excreted during the light period, while a decrease in these substances occurred in the following dark period. They concluded that these polymeric compounds were reassimilated by the $P$. pouchetii cells to cover the carbon and energetic needs of the cells in the dark. Guillard \& Hellebust (1971) as well as Lancelot \& Mathot (1985) used the classical filtration technique, and although gentle filtration pressure was used the colonies tended to collapse on the filter so that the distribution of organic compounds over the colony and the surrounding medium cannot be assessed. The present study analyses the flux of organic substances from the $P$. pouchetii cells into the intracolonial fluid, and from the colonies into the surrounding medium, and tries to identify the molecular size of the compounds involved.

Material and Methods. A unialgal culture of Phaeocystis pouchetii, isolated from the North Sea along the Dutch coast, was grown in a synthetic seawater medium (Admiraal \& Werner 1983), whereby nitrate and phosphate were added in lowered concen- 
trations of 67.5 and $3.6 \mu \mathrm{M}$, respectively. Silicate was omitted, but the following vitamins were added: $50 \mu \mathrm{g}$ $1^{-1}$ calcium-D-panthotenate; $1 \mu \mathrm{g} \mathrm{l^{-1 }}$ folic acid; $2.5 \mathrm{mg}$ $\mathrm{l}^{-1}$ inositol; $50 \mu \mathrm{g} \mathrm{I}^{-1}$ nicotinic acid; $15 \mu \mathrm{g} \mathrm{l}^{-1}$ thymine. $P$. pouchetii cells had a growth rate $(\mu)$ of $1.39 \mathrm{~d}^{-1}$ in this medium when the colonies were small and the density of the culture was low. In later stages, when a total density of $95 \times 10^{6}$ cells $1^{-1}$ was reached, growth rate dropped to $0.34 \mathrm{~d}^{-1}$. At that stage the ca $4 \mathrm{~mm}$ diameter colonies were used for experiments. About 20 min before the start of the light period $60 \mu \mathrm{Ci}{ }^{14} \mathrm{C}$ $\mathrm{NaHCO}_{3}$ (Amersham) was added to $600 \mathrm{ml}$ of culture. The $P$. pouchetii culture was placed on a rolling device (3 rpm) that provided a gentle mixing. Temperature was $11^{\circ} \mathrm{C}$, irradiance $200 \mu$ Einst $\mathrm{m}^{-2} \mathrm{~s}^{-1}$ for a period of $12 \mathrm{~h}$, followed by a dark period of $12 \mathrm{~h}$. At different time intervals triplicate subsamples ( $25 \mathrm{ml}$ each) were used to obtain 2 filtrates, A and B. Before filtration one of the samples remained stationary for a few minutes so that the colonies could sink.

The upper part of the culture liquid, without colonies, was then decanted and filtered on membrane filters (pore size $0.45 \mu \mathrm{m}$, Sartorius 11106) under low pressure $(<100 \mathrm{~mm} \mathrm{Hg})$. Care was taken to dispose of the last few $\mathrm{ml}$ of the culture before it passed through the filter to ensure that no colonies or cells were damaged by the filtration, thus ensuring that this first filtrate (A) only contained extracolonial substances. The second well-suspended sample of $25 \mathrm{ml}$ was then filtered and washed 3 times with $2 \mathrm{ml}$ of artificial sea water. In addition to extracolonial substances, Filtrate $\mathrm{B}$ also contains intracolonial substances derived from algal colonies collapsed on the filter. The material remaining on this filter was used to measure cellular production. The third sample was treated as Filtrates A. or $B$ and served as a control. Organic production in both filtrates was calculated from the activity remaining in the filtrate after purging the inorganic carbon. ${ }^{14} \mathrm{C}$ carbonates were removed by 25 min bubbling of filtrates, acidified to $\mathrm{pH} 2.5$ with $6 \% \mathrm{H}_{3} \mathrm{PO}_{4}$.

Samples of $5 \mathrm{ml}$ of both types of filtrate (A and B) were freeze-dried and then re-dissolved in 0.5 to $1 \mathrm{ml}$ water. The re-dissolved sample was fractionated according to molecular weight on a $90 \times 2 \mathrm{~cm}$ large column of polyacrylamide gel (Biogel $\mathrm{P}_{2}$ i exclusion limit MW 1800). The column was eluted with $0.5 \mathrm{M}$ $\mathrm{NaCl}$ and $3 \mathrm{ml}$ aliquots were collected. The activity of these fractions and of the filtrates (A \& B) was determined by adding a 2 -fold volume of Instagel II before counting in a Packard Tricarb $460 \mathrm{CD}$. Activity of the filters was measured after adding $0.8 \mathrm{ml}$ propylacetate and $5 \mathrm{ml}$ Instagel II. Elution patterns observed of untreated and freeze-dried samples were similar.

Results and Discussion. Fig. 1 shows that in the light Phaeocystis pouchetii colonies released considerable

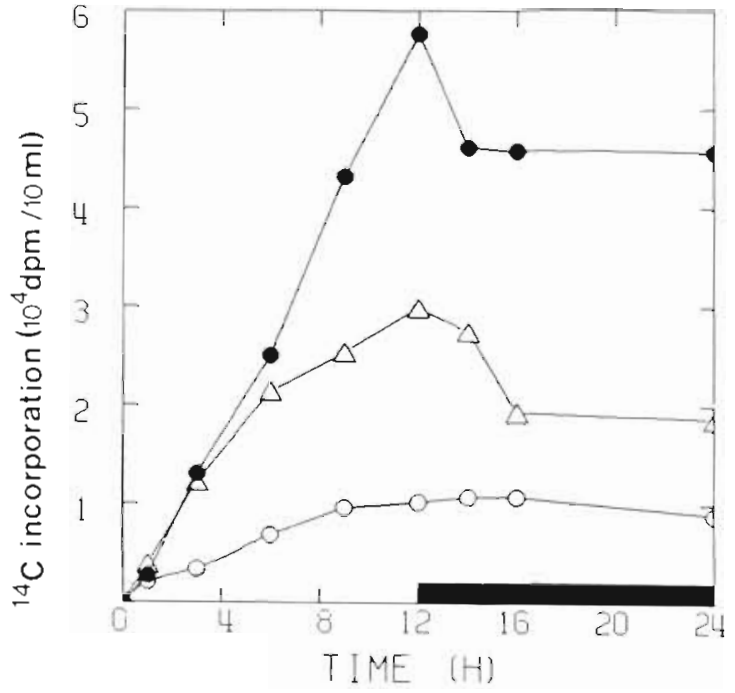

Fig. 1. Phaeocystis pouchetii. Kinetics of inorganic carbon incorporation in $4 \mathrm{~mm}$ colonies. particulate; $O$ extra-colonial (Filtrate A); $\triangle$ intra- + extracolonial (Filtrate B). Black bar: dark period

amounts of ${ }^{14} \mathrm{C}$-labeled compounds as extracellular material. After $6 \mathrm{~h}$ of illumination, $46 \%$ of the total photosynthetic production was found in Filtrate B, containing the total extracellular material. This observation confirms the earlier observations on the high excretion percentages measured for $P$. pouchetii (Guillard \& Hellebust 1971, Lancelot 1984). However, the filtration procedure leading to truly extracolonial substances (Filtrate A) shows that after 6 h only $14 \%$ of the total photosynthetic production was liberated in the surrounding medium (Fig 1). Moreover, the 2 fractions - extracellular and extracolonial - showed a different response over the light/dark period. The total amount of extracolonial substances remained constant in the dark, suggesting that the production of extracolonial compounds is strongly coupled to cellular photosynthesis. In contrast, diatoms continue their excretion in the dark (Mague et al. 1980). Hence, the excretion by $P$. pouchetii included processes differing from those in diatoms. Lancelot \& Mathot (1985) postulate the resorption of extracellular macromolecules by colonial $P$. pouchetii cells in the dark. Fig. 1 confirms this interpretation and indicates that the substances subject to resorption are located inside the colony.

The extracolonial fraction is dominated by a single organic compound produced during the light period. This compound remains constant during the following dark phase (Fig. 2A). The position of this compound in the gel filtration pattern does not correspond with any of the tested reference substances, so its nature remains unclear. In the colony a variety of other organic compounds is found (Fig. 2B) mainly consisting of large-molecular-weight compounds ( $M W>$ 
1800) produced during the light period. In the first few hours of the next dark period, however, these large molecules disappeared; instead, a series of small and intermediately sized molecules was observed. The dominant compound in the extracolonial material, eluted at $95 \mathrm{ml}$, was not represented in the colony in significant amounts, since the radioactivity of this material in the extracellular material was not higher than in the extracolonial material (Fig. 2). This obser-
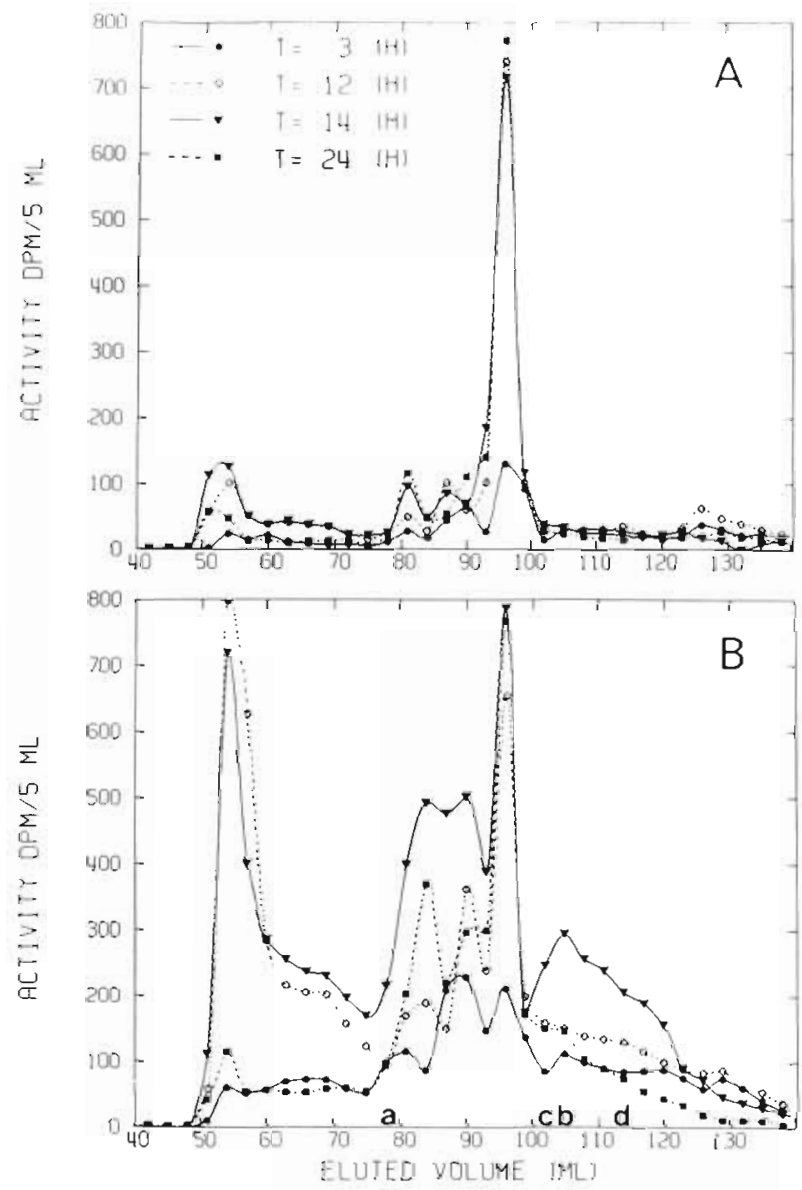

Fig. 2. Phaeocystis pouchetii. Elution pattern of extracolonial (A) and extracolonial plus intracolonial substances (B) after gelfiltration. a to d indicate the position of different markers found in reference runs. a: vitamin $\mathrm{B}_{12}(\mathrm{MW} 1355)$; $\mathrm{b}:{ }^{14} \mathrm{C}$ glucose (MW 183); c: ${ }^{14} \mathrm{C}$-leucine (MW 133); d: ${ }^{14} \mathrm{C}-\mathrm{HCO}_{3}^{-}$ (MW 63); $\mathrm{T}=$ time in $\mathrm{h}$ after addition of ${ }^{14} \mathrm{C}$-bicarbonate (see Fig. 1)

vation indicates a rapid permeation of this compound through the colony membrane, whereas the other colonial compounds are retained. Lancelot \& Mathot (1985) concluded that the extracellular compounds of Phaeocystis pouchetii function as reserve products, covering the carbon and energetic needs of the colonies in the dark. Previous observations by Guillard \& Hellebust (1971) seem to agree with this interpretation, since the extracellular material consisted of macromolecular carbohydrates. However, we observed a massive turn-over of colonial macromolecules only in relative large colonies with slowly dividing cells. It seems unlikely to us that these well-illuminated cultures are truly subject to light or carbon limitation. As an alternative hypothesis we propose that the rapid turn-over of colonial material, seen especially during light-dark transition, is part of the processing of superfluous photosynthates in nutrient limited relative large colonies. Hence, this effect may be interpreted also as a kind of over-flow metabolism.

Is the turn-over of colonial macromolecules subject to bacterial attack? The matrix of Phaeocystis pouchetii colonies may contain particles, bacteria and even diatoms. The culture used in the present work was isolated and grown aseptically, but was probably not completely bacteria-free. Yet the bacterial activity during the light period as measured with the ${ }^{3} \mathrm{H}$-thymidine method (Fuhrman \& Azam 1982) was very low. Less than $0.3 \times 10^{-3} \mathrm{nmol}$ thym $\mathrm{l}^{-1} \mathrm{~h}^{-1}$ was incorporated as opposed to value of $>5 \times 10^{-3} \mathrm{nmol}$ thym $\mathrm{l}^{-1}$ $\mathrm{h}^{-1}$, measured during $P$. pouchetii blooms in the field (unpubl. own obs.). Hence bacteria in the present cultures of $P$. pouchetii are unlikely to interfere with the consumption of organic substrates as intensively as they do in natural populations. Yet, the turn-over of colonial macromolecules was seen in the cultures as well as in natural populations (Lancelot \& Mathot 1985, unpubl. own obs.), indicating that the recycling is mainly due to algal metabolism. The production of antibiotics by $P$. pouchetii (Sieburth 1960) in nature possibly functions as a protective mechanism of the intracolonial carbon cycle.

Major fluxes of the organic material in the colonial matrix can occur quite rapidly: within the first 4 h of the dark period up to $57 \%$ of the intracolonial material produced in the preceding light period seems to be resorbed for biosynthetic and metabolic purposes (Fig. 1). However, production of these intracolonial substances seems to be highest in slow growing or stationary phase Phaeocystis pouchetii with large colonies, usually found towards the end of the bloom (Lancelot 1984, Veldhuis unpubl.). We found the effects described here also in natural populations and in fast-growing cultures with very small colonies. In the latter case the production of intracolonial substances amounted to only $3 \%$ of the photosynthetic production. This indicates that colonial cells remain intact during the filtration procedure used by us.

This study implies that great care must be taken when measuring the extracellular release by algal colonies and gelatinous phytoplankton species, especially in field studies. The results indicate that a significant fraction of the gelatinous material of 
Phaeocystis pouchetii should be regarded as a metabolically active material.

Acknowledgement. We are indebted to Drs F. Colijn, C. van den Hoek, C. Lancelot, W W. C. Gieskes and M. Cambridge for critical comments on the manuscript.

\section{LITERATURE CITED}

Admiraal, W., Werner, D. (1983). Utilization of limiting concentrations of ortho-phosphate and production of organic phosphates in cultures of marine diatoms. J. Plankton Res. 5: 495-513

Boalch, G. T., Harbour, D. S. (1977). Unusual diatom off the coast of Southwest England and its effect on fishing. Nature, Lond. 269: 687-688

Boney, A. D. (1981). Mucilage: The ubiquitous algal attribute. Br. phycol. J. 16: 115-132

Bougard, M. (1979). Etude bibliografique sur le phytoflagelle Phaeocystis. Institut de biologie maritime et regionale de Wimereux, Université des sciences et technique de Lille

Fuhrman, J. A., Azam, F. (1982). Thymidine incorporation as a measure of heterotrophic bacterio plankton production in marine surface waters: evaluation and field results. Mar. Biol. 66: 109-120

Guillard, R. R. L., Hellebust, J. A. (1971). Growth and the production of extracellular substances by two strains of Phaeocystis pouchetii. J. Phycol. 7: 330-338

Haug, A., Myklestad, S. (1976). Polysaccharides of marine diatoms with special reference to Chaetoceros species. Mar. Biol. 34: 217-222

Joiris, C.. Billen, G., Lancelot, C., Daro, M. H., Mommaerts, J. P., Bertels, A., Bossicort, M., Ni js, J., Hecq. J. H. (1982). A budget of carbon cycling in the Belgian coastal zone: relative roles of zooplankton, bacterioplankton and benthos in the utilization of primary production. Neth. J. Sea Res. 16: 260-275

Kugrens, P., West, J. A. (1973). The ultrastructure of carpospore differentiation in the parasitic red alga Levringiella gardneri (Setch.) Kylin. Phycologia 12: 163-173

Lancelot, C. (1984). Metabolic changes in Phaeocystis pouchetii (Hariot) Lagerheim during the spring bloom in Belgian coastal waters. Estuar coast. Shelf Sc. 18:65-77

Lancelot, C., Mathot, S. (1985). Biochemical fractionation of primary production by phytoplankton in Belgian coastal waters during short and long-term incubations with ${ }^{14} \mathrm{C}$ bicarbonate. II. Phaeocystis pouchetii colonial population. Mar. Biol. 86: 227-232

Mague, T H., Friberg, E., Hughes, D. J., Morris, I. (1980). Extracellular release of carbon by marine phytoplankton; a physiological approach. Limnol. Oceanogr. 25: 262-279

Myklestad, S., Haug, A. (1972). Production of carbohydrates by the marine diatom Chaetoceros affinis var. willei. (Gran) Hustedt. I. Effect of the concentration of nutrients in the culture medium. J. exp. mar. Biol. Ecol. 9: 125-136

Pentecost, A. (1983). The distribution of daughter colonies and cell numbers in a natural population of Volvox aureus Ehrenb. Ann. Bot. 52: 769-776

Reynolds, C. S., Rodgers, M. W. (1983). Cell and colonydivision in Eudorina (Chlorophyta: Volvocales) and some ecological implications. Br. phycol. J. 18: 111-119

Round, F. E. (1984). The ecology of algae. Cambridge Univ. Press., Cambridge

Smayda, T. J. (1970). The suspension and sinking of phytoplankton in the sea. Oceanogr. mar. Biol. A. Rev. 8: $353-414$

Sieburth, J. McN. (1960). Acrylic acid, an 'antibiotic' principle in Phaeocystis blooms in Antarctic waters. Science 132: 676-677

Walsby, A. E., Reynolds, C. S. (1980). Sinking and floating. In: Morris, I. (ed.) The physiological ecology of phytoplankton. Blackwell Scient. Publ., Oxford, p. 371-412

Accepted for printing on August 8, 1985 